Pregledni znanstveni članek Review scientific paper (1.02) Besedilo prejeto Received: 16. 5. 2019; Sprejeto Accepted: 25. 5. 2019

\title{
Cvetka Rezar
}

\section{Slomškov pogled na jezikovno vzgojo v bogoslovni šoli}

\author{
Slomšek's View on Linguistic Education \\ in Theological School
}

Povzetek: Anton Martin Slomšek je jezikovno vzgojo razumel kot eno pomembnejših v bogo-
slovnem študiju in si zanjo prizadeval na različne načine. Tako je že kot bogoslovec in pozneje
kot spiritual v celovškem bogoslovju vodil tečaje slovenščine, ob pomanjkanju primernih
priročnikov pa pripravil tudi nemško pisano slovensko slovnico in priročnik cerkvenega
govorništva. S tem je Slomškova jezikovna vzgoja bodočih duhovnikov imela širši pomen, saj
si je z njo intenzivno prizadeval izboljšati slovensko šolstvo in v njem utrditi mesto slovenšči-
ne, ki ji je z vidika enakopravnosti pripadalo ob prevladujoči nemščini. Njegovo jezikovno
delo pa je imelo tudi dolgoročne vplive, saj je z njim pripravljal temelje za nadaljnje razvijanje
dogodkov ob prestavitvi škofijskega sedeža in začetkih visokega šolstva v Mariboru. Ne na-
zadnje pa njegovo razumevanje slovenščine ostaja aktualno pri sodobnem jezikovnem načr-
tovanju maternega jezika v slovenskem izobraževalnem sistemu - tudi na visokošolski stopnji.

Ključne besede: Slomšek, pouk slovenščine, slovenski učni jezik, 19. stoletje, bogoslovna šola, visoko šolstvo

\begin{abstract}
Anton Martin Slomšek considered linguistic education as one of the most important in theological studies and strived for it in various ways. As a theology student and later as a spiritual in Klagenfurt seminary he carried out classes of Slovene, and the lack of appropriate study books made him put together Slovene grammar in German and a study book of ecclesiastic rhetoric. Thus, Slomšek's linguistic education of future clergy had a wider meaning, because he intensively tried to improve the Slovene education and reinforce the position of the Slovene language within it, which was from the view of equality entitled to alongside the prevailing German. His linguistic work also had long-term influences, by which Slomšek prepared the basis for further development of events at the time the diocesan headquarters was being moved and the beginnings of higher education in Maribor were taking place. Last but not least, his understanding of Slovene language remains up-to-date in modern linguistic planning of mother tongue in the Slovene educational system - as well as on the level of higher education.
\end{abstract}

Key words: Slomšek, Slovene classes, Slovene language of instruction, $19^{\text {th }}$ century, theology studies, higher education 


\section{Uvod}

Kolikšno skrb je Slomšek namenjal bogoslovni vzgoji, nam kaže njegovo raznovrstno delo najprej v celovškem bogoslovju, ki je bilo skupno za krško in lavantinsko škofijo, nato po letu 1850 ob prestavitvi četrtega letnika lavantinskih bogoslovcev iz Celovca v Šent Andraž, ne nazadnje pa ob prenosu lavantinske škofije v Maribor leta 1859, ko je 11. oktobra začela delovati tudi (Visoka) bogoslovna šola. Eden najpomembnejših elementov teh Slomškovih prizadevanj je bila jezikovna vzgoja - skrb za slovenski materni jezik, ki jo je z izjemno vnemo uresničeval vse svoje življenje.

\section{Tečaji slovenščine v celovškem bogoslovju}

Slomšek je eno svojih prvih in zgodnjih jezikovnih prizadevanj namenil prav bogoslovcem. Že kot sam bogoslovec je namreč zelo hitro spoznal, da je ob dobrem bogoslovnem šolanju zelo pomembno tudi jezikovno znanje, saj so duhovniki med najpomembnejšimi posredovalci maternega jezika med najširše ljudstvo. Po Kovačičevem poročanju $(1934,35)$ je Slomšek med takratnimi bogoslovci slovenščino najbolj obvladal; tako je že v letih od 1821 do 1823 po vzoru ljubljanske stolice začel tečaje slovenščine (Jesenšek 2010, 668-669), ki jih je vodil najprej za bogoslovce krške in lavantinske škofije, pozneje pa tudi za nemške uradnike. V uvodnem nagovoru ${ }^{1}$ je svoje vrstnike opozoril na slabo znanje slovenščine med duhovniki, ki delujejo med slovenskim ljudstvom. Postavljal jih je ob bok »vojaku, ki se hoče brez orožja bojevati, in delavcu, ki gre v vinograd kopat - brez motike«. Ob tem je poudaril, da mora duhovnik nauk ljudstvu podajati v dostojni, olikani obliki, kar pomeni, da mora najprej sam obvladati jezik. Izrazil je nujnost učenja pa tudi uporabljanja slovenskega jezika. Nasprotoval je jezikovnemu odpadništvu in opozarjal, da z izobrazbo ne sme rasti odpor do maternega jezika, saj je slovenski jezik primeren tudi za izobražence. Bodoče duhovnike je posebej spodbujal, naj v letih pripravljanja na duhovništvo skrbijo za slovenski jezik in za slovenske 
šole ter pišejo knjige za svoje rojake, sam pa jim je pri tem ponudil pomoč s svojimi jezikovnimi urami.

Slomškovi tečaji slovenščine so bili najprej prostovoljni, ko pa jih je nadaljeval kot spiritual (od 1829 do 1838), je krški škof Mayr svojim bogoslovcem zapovedal obvezno udeležbo, saj se je zavedal koristnosti slovenskega jezikovnega pouka, medtem ko je lavantinski škof Zimmermann vztrajal pri prostovoljni udeležbi (Grafenauer 1958-1959, 279-280). Kot že prej je Slomšek tudi kot spiritual ob teh tečajih svoje gojence ozaveščal o materinščini kot najdragocenejši dediščini, ki jo je treba skrbno negovati, kar je utemeljeval tudi z njeno bogato zgodovino. Vsestransko delo na področju slovenskega jezika je razumel v neločljivi povezanosti z duhovniškim poslanstvom. V celovškem bogoslovju so ti tečaji po Slomškovem odhodu zamrli, čeprav si je škof Mayr prizadeval, da bi jih nadaljevali naslednji spirituali (Grafenauer 1958-1959, 282).

Slomškovi tečaji so veljali za zelo uspešne, saj je bil Slomšek dober učitelj (Grafenauer 1958-1959, 280). Z njimi bodočih duhovnikov ni samo učil jezika, temveč je vzgajal tudi bodoče pisatelje in z njimi ustvarjal slovensko mladinsko slovstvo (Kovačič 1934, 76). Vrednost Slomškove tako imenovane celovške stolice za koroške in štajerske Slovence je primerljiva delu, ki ga je takratna graška stolica ${ }^{2}$ slovenskega jezika dala štajerskim visokošolcem mariborskega okrožja sekovske škofije in ljubljanska ${ }^{3}$ Metelkova kranjskim (Orožen 1996, 106). S tem je tudi pomembno vplival na razvoj slovenskega šolstva in slovenske prosvete (Grafenauer 1958-1959, 272), saj se je $\mathrm{z}$ jezikovnim poukom $\mathrm{v}$ bogoslovjih posledično na visokih šolah začela uvajati nova slavistična in slovenistična veda (Grafenauer 1958-1959, 282). Ne nazadnje je Slomšek s tem delom med takratnimi celovškimi (Jarnik, Ahacl) in graškimi jezikoslovci (Murko, Caf, Muršec, Miklošič) v jezikovni praksi sooblikoval zasnovo poenotenega slovenskega knjižnega jezika in v tem duhu vzgajal tudi duhovnike (Orožen 1996, 108).

2 Na njej je slovenski jezik učil Janez Nepomuk Primic (1812-1813), vendar stolica po njegovi bolezni in smrti nekaj časa ni delovala, ponovno je bila vzpostavljena šele 1823 (Grafenauer 1958-1959, 274). Udeležba bogoslovcev je bila obvezna šele od leta 1827.

3 Franc Metelko je leta 1817 na njej začel predavanja slovenskega jezika, ki so bila obvezna za bogoslovce drugega letnika (Grafenauer 1958-1959, 277). 


\section{Slovnica Inbegriff der slowenischen Sprache für Ingeborne}

Slomškovi jezikovni tečaji v celovškem bogoslovju so za takratne razmere veljali za pogumno in težko delo, saj ni bilo primernih jezikovnih priročnikov niti knjig za branje. Zato je Slomšek iz potrebe, da bi bilo to delo lažje za njegove slušatelje, verjetno že v prvem letniku (1821) bogoslovja začel pripravljati slovnico z naslovom Inbegriff der slowenischen Sprache für Ingeborne ${ }^{4}$ prilagojeno poučevanju v celovškem bogoslovju, in pri tem uporabljal berila in slovnice tudi drugih avtorjev. ${ }^{5}$

Čeprav ni bil jezikoslovec oziroma slovničar (Jesenšek 2010, 672, 675; Orožen 1996, 104), je to delo pripravil kot skrben zapisovalec jezika oziroma njegov ljubitelj in skrbnik. V jezikovnih vprašanjih je pogosto nastopal kot razsodnik, predvsem pa je o jeziku pisal objektivno in na podlagi izkušenj ter praktičnih pogledov na jezik. Slomškova slovnica ima v ozadju romantično težnjo po jezikovnem poenotenju kot pogoju za narodnostno združitev Slovencev (Jesenšek 2010, 672) in hkrati razsvetljensko težnjo z jezikovnim ozaveščanjem prebuditi slovenski narod in ga poučiti o bogastvu slovenščine kot maternega jezika.

Slovnica, sicer pisana v nemškem jeziku s slovenskimi zgledi, v osrednjih treh delih obravnava glasoslovje, oblikoslovje in skladnjo, na začetku pa je dodan kratek uvod in na koncu dodatek ter test iz slovenskega jezika. V uvodu opozori na širino raziskovanja posameznega jezika, ki ga človek, podobno kot vesolja, ne more nikoli povsem raziskati. Učenje jezika se začne z rojstvom, v polnosti pa se ne konča niti ob smrti. Jezik primerja z vrtom, posejanim z besednimi oblikami, ki ga mora učitelj negovati in z njegovimi sadovi hraniti narod.

4 Slovnico hrani UKM, rokopis pod signaturo Ms 167, prepis pa pod signaturo Ms 318.

5 Na primer Kopitarjevo, ki pa je bila za bogoslovce prezahtevna in didaktično neprimerna, Metelkovo, ki je bila zaradi pisave (metelčice) nerodna in premalo vseslovenska, predvsem pa Murkovo slovnico in slovar, ki ju je prepoznaval za združevalna pri poenotenju slovenskega knjižnega jezika (Jesenšek 2010, 669, 671). 


\section{Govorniški priročnik Vaje cerkvene zgovornosti}

Ob svojih jezikovnih urah v celovškem bogoslovju je Slomšek svoje poslušalce učil tudi cerkvenega govorništva. Najprej jim je dal prevajati odlomke iz besedil cerkvenih očetov, ki jih je nato sam slogovno in jezikovno pilil, nato pa so bogoslovci s temi besedili tudi nastopili. Ker pa je ob njihovem slabem znanju materinščine opažal velik primanjkljaj tudi na govorniškem področju, ${ }^{6}$ je zanje pripravil priročnik Vaje cerkvene zgovornosti. $\mathrm{V}$ duhovnikih je namreč videl pomembne posredovalce kultiviranega jezika za preproste ljudi, zato je še toliko večjo skrb namenjal njihovemu opismenjevanju in kulturi govora. Pripravil jim je govorna in pisna pravila, kako naj govornik govor ureja, ga razdeli, se ga nauči in izvaja, ter jih o njih zavzeto poučeval. S tem je pomembno prispeval k oblikovanju cerkvenega govorništva v 19. stoletju in hkrati k oblikovanju knjižne izreke, saj je s konkretnimi retoričnimi navodili pokazal, kako je treba jezik usposobiti za pisanje in javno govorniško nastopanje. Gre za govorniška načela in spoznanja, znana že pri antičnih govornikih, vendar krščansko obarvana in prilagojena slovenskemu jeziku in kulturi. Čeprav so Vaje prvotno govorniški priročnik, v njih prepoznavamo pomembnejše Slomškove praktične poglede na jezik, saj je bil jezik zanj eden temeljnih elementov v govorništvu. Vaje tudi nakazujejo Slomškovo temeljno naravnanost k živemu »judskemu« jeziku, ki ga je treba neprestano kultivirati (Orožen 1996, 122).

Slomšek meni, da mora govornik najprej dobro poznati pravila za oblikovanje govora in obliko govorov, spoznavati druge govornike, predvsem pa obvladati snov, o kateri govori. $\mathrm{V}$ govorništvu je pomemben tako talent kot tudi vaja. V uvodu poudari, da je za bodočega govornika pomembna vaja $\mathrm{v}$ glasnem branju, pripovedovanje po spominu, oblikovanje nejezikovnih elementov, poznavanje različnih vrst govorov in drugih učinkovitih pripomočkov, ki so mu lahko v pomoč.

6 Ko je bila s Thunovo šolsko reformo (1848) v gimnazijah ukinjena retorika, je Slomšek v tem prepoznaval veliko škodo za jezik in kulturo javnega nastopanja, zato je za tako izobraževanje med bodočimi duhovniki poskrbel sam. 
V prvem poglavju Slomšek govori o besedi/izvedbi ${ }^{7}$ kot o najpomembnejšem pri govorništvu. Na eni strani predstavlja njeno slušno uresničitev, na drugi strani pa vizualno, pri čemer sta neločljivo povezana jezik in telo. Najprej poudari, da je za govornika temeljnega pomena dobro poznavanje in obvladanje maternega jezika; ob tem je treba upoštevati pravilen izgovor glasov, besedne poudarke/naglasna mesta, stavčno intonacijo, knjižno izreko, jakost, hitrost in čustveno barvanje glasu.

V drugem poglavju govori o nebesednih spremljevalcih govora oziroma o njegovi vidni uresničitvi, in sicer o telesni drži govornika, obrazni mimiki, podrobneje pa o kretnjah rok in drugih telesnih gestah.

Tretje poglavje govori o tem, kako naj si govornik prizadeva za »svoje blago«, kako naj bogati svoje znanje z izobraževanjem, branjem drugih del, pisanjem in ubeseditvijo, kako naj prevzema iz drugih jezikov v slovenščino, kako naj spodbudi osebno zavzetost za delo, kritično ocenjuje svoj govor, stremi k njegovi kakovosti ter si prizadeva za nenehno izpopolnjevanje ter spoznavanje značajev, časa, krajev in ljudi, čemur se trudi prilagoditi svoj govor.

Četrto poglavje najprej opozori na postopno rast v govorništvu, nato pa govori o moralni podobi govornika, o vrlinah, za katere naj si prizadeva, ter o negativnih lastnostih, ki naj se jih izogiba. Spodbuja k dobremu spoznavanju samega sebe pa tudi k dobremu poznavanju naslovnikov, kar je pomembno za učinkovitost govora.

V petem poglavju Slomšek predstavi osem pravil, po katerih naj govornik išče, izbira, obdeluje in smiselno razvršča gradivo, tudi glede na konkretnega naslovnika; pri tem še poudari pomen izvirnosti in tudi obsega. Spregovori še o besedi/temi, ki naj bo razumljiva konkretnemu naslovni$\mathrm{ku}$, jedrnata in aktualna.

V šestem poglavju govori o jezikovni podobi govora. Govornika spodbuja k skrbi za slovenski jezik in za ohranjanje tako knjižnega jezika kot

7 Dermol Hvala $(2004,111)$ opozarja, da je Slomšek pronunciatio prevajal z »beseda«, dejansko pa gre za izvedbo. 
tudi jezika preprostega ljudstva. Spodbuja tudi k rabi slovenskega besedja in slovenskih skladenjskih vzorcev. Nato predstavi različne vrste stila, npr. slovesnega, veselega in žalostnega. Priporoča rabo besednih figur in dobro znanih domačih podob, vendar pa svari pred njihovo pretirano uporabo. Na koncu poglavja še opozori na duhovno moč besede, ki ji v govorništvu pripisuje velik pomen in jo teološko utemeljuje kot dar Svetega Duha.

Sedmo poglavje obravnava razporeditev govorne snovi. Slomšek na prvo mesto postavi izdelavo osnutka. Govor naj bo razdeljen na "začetek, dokazek in konec«, ki naj sledijo svojemu namenu, prilagojen pa naj bo konkretnim okoliščinam. V uvodu je treba poslušalce pritegniti, nato pa jim kratko predstaviti temo govora, $v$ nadaljevanju sistematično razčlenjeno na posamezne dele. Pri tem opozori, naj posamezni deli prehajajo drug v drugega. $\mathrm{V}$ jedru govora ima osrednje mesto dokazovanje, ki mora biti prilagojeno konkretnim naslovnikom. Sklepni del predstavi kot »venec celega govora», saj z njim neposredno nagovarja poslušalce k uresničitvi pridižnega namena. Pomembno je, da je govornik najprej sam navdušen nad tem, kar govori. Predstavi še načine, kako naj govornik vnema poslušalce.

V osmem poglavju najprej predstavi posamezne vrste govorov in pri vsakem razloži, kako naj bo pripravljen in oblikovan. Nato posebej spregovori o pridigi, ki je na "naj imenitnejem mestu po svoji slovesnosti in obsegi ter ima svoje posebne pravila«. Razloži njeno obvezno zgradbo, ki jo veže na antično delitev govora. Pridiga mora obsegati naslov ali predgovor, uvod ali vpeljavo, razlago ali dokaz in sklep. Po zgradbi se torej deli na tri glavne odstavke, ki so razdeljeni še naprej. Predgovor oziroma naslov mora pridigar vzeti iz Svetega pisma ali cerkvenih verskih pravil in mora biti kratek in razumljiv, saj je to jedro in izhodišče vsega govora. Uvod (exordium) je zelo pomemben, saj se mora govornik v njem čim bolj približati svojim poslušalcem, jim razodeti namen pridige in jih usmeriti v glavno temo. Opozarja tudi na izvirnost, kratkost in jedrnatost ubeseditve v uvodu, ki mora vzbujati radovednost in privlačnost. V jedrnem delu sledi razlaganje in dokazovanje, ki mora biti razumljivo in podprto s Svetim pismom, izreki cerkvenih očetov in drugimi zgledi. Pri tem še dodaja, naj govornik dokazovanje prilagodi okoliščinam poslušalcev. Govornik naj dokazuje tako, da se bodo poslušalci čutili nagovorjene in jih bo to vodilo v preobrazbo. Najpomembnejši del je sklep, v katerem mora govornik še enkrat ponoviti osrednjo misel pridige in osvežiti njen namen. Pridigo 
naj sklene bodisi z zgledom bodisi z molitvijo ali pa izrekom oziroma samo z vzdihljajem.

Deveto poglavje obravnava poimenovanje oseb. Slomšek svetuje poimenovanje poslušalcev le na začetku in kadar je resnično potrebno. Dodaja nekaj konkretnih ogovornih oblik in v poimenovanju priporoča uporabo moškega spola, pri posebnih poudarkih pa obeh. Nato še opredeli vikanje, onikanje in tikanje.

Zadnje, deseto poglavje priporoča branje dobrih govorniških zgledov in spodbuja $\mathrm{k}$ njihovemu posnemanju ter h govorjenju »na pamet«. Govornika nagovarja, naj da svoje delo v presojo drugim modrim govornikom in ob posnemanju kakovostnih govorniških zgledov ohranja svojo in slovensko izvirnost v govorništvu.

Slomškove Vaje so prvi tak slovenski priročnik z brezčasno vrednostjo, po obsegu sicer skromen, a z bistvenimi spoznanji javnega nastopanja. Namenjen ni bil le duhovnikom, ampak po svoji jasnosti in nazornosti tudi drugim. Aktualen je še danes, saj »sistematično in izčrpno obravnava vse prvine jezikovnega oblikovanja od zvočnih do širše semiotičnih in modalnopomenskih razsežnosti jezikovne zgradbe, od vsebinske strukture in tipologije govorov do kompozicije idejnovsebinsko in stilistično ustrezno naravnanega besedila«(Orožen 1991, 374).

\section{Vpliv Slomškove jezikovne vzgoje na slovenščino v šoli}

Slomškova jezikovna vzgoja bodočih duhovnikov v celovškem bogoslovju je imela širši pomen, saj si je Slomšek z njo intenzivno prizadeval izboljšati slovensko šolstvo in ga utemeljiti na slovenskem maternem jeziku (Rezar 2014, 45-69). Takratne družbenopolitične razmere so bile namreč nenaklonjene razvoju maternega jezika v šolstvu. Pouk slovenščine je bil podrejen nemščini, prevladujoče nemške šole pa otrokom niso prinesle pravega znanja jezika, niti nemščine in še manj slovenščine. Slomšek je opozarjal, da so iz takih razmer v šolstvu prihajali slovenski izobraženci, ki niso znali slovensko in so se slovenske besede celo sramovali ter tako med slovenstvom razširjali germanistične ideje. 
Slomšek se je zavedal, da je za zagotavljanje narodnih svoboščin znotraj skupne države ob slovenskem jeziku potrebna tudi slovenska šola (Jesenšek 2003, 669). Zato je kot spiritual mlade bogoslovce spodbujal $\mathrm{k}$ razširjanju nedeljskih šol, v katerih je postavil »slovenski jezik v podlago vsega učenja», nemščina pa je bila le učni predmet. Na ta način je želel posredno vplivati na redno slovensko šolstvo in pouk urediti na podlagi maternega jezika, saj je bil prepričan, da je materinščina bistvenega pomena za začetni pouk.

Na načrtovanje šolstva na Slovenskem je pozneje vplival kot šolski nadzornik za lavantinsko škofijo in nato svetoval tudi avstrijskemu šolskemu ministru grofu Leonu Thunu. Tako je lahko vplival na usodo slovenščine v učnih načrtih, kar ga je kot predstavnika Cerkve in kot velikega ljubitelja slovenščine posebej zanimalo.

Pri preureditvi slovenskega šolstva je zagovarjal, da mora začetni pouk potekati v maternem jeziku. Glede dvojezičnih šol je menil, da jih je treba ustanoviti tam, kjer je znanje nemščine potrebno, pri čemer naj se šolski pouk uredi tako, da se otroci slovenskih staršev učijo nemško, otroci nemških staršev pa slovensko. Kjer pa ni nujnosti dvojezičnega pouka, naj bodo le slovenske šole z osnovami nemščine. Prepričan je bil, da učenje nemškega jezika v ljudskih šolah ne sme potekati na škodo za narodovo izobrazbo potrebnih predmetov. $Z$ vidika enakopravnosti pa je za vse nemško govoreče na slovenskem ozemlju zahteval učenje slovenščine. Odločno je tudi nasprotoval, da bi bil verouk v šoli sredstvo za učenje tujega jezika, zato tudi ni dovoljeval dvojezičnih katekizmov.

Slomškovo razumevanje jezikovnega pouka na Slovenskem je bilo skladno z njegovimi pogledi na enakopravni položaj slovenskega učnega jezika v skupni avstrijski državi, vendar v praksi ni bilo popolnoma uveljavljeno (Jesenšek 2003, 672).

\section{Aktualnost Slomškove jezikovne vzgoje v sodobnem izobraževalnem sistemu}

Slomškov pogled na jezikovno vzgojo je aktualen tudi v sodobnosti, zlasti ko »ugotavljamo opazno krnjenje strokovne slovenščine na vseh stopnjah 
šolanja« (Žele 2018, 94). Kot se je Slomšek v svojem času odločno uprl tujim jezikovnim vplivom, bi se danes verjetno uprl težnjam, da bi angleščino sprejeli kot nadomestni učni jezik. Podobno bi zagovarjal edinstvenost in enakovrednost slovenščine ob angleščini. Zagotovo bi spodbujal učenje angleščine kot tujega jezika, odločno pa bi zavračal, da bi to učenje potekalo na škodo učnih predmetov, potrebnih za temeljno narodovo izobrazbo. V ozadju je namreč še vedno ideja o neprimernosti in nerazvitosti slovenskega učnega jezika, ki omogoča vedno večji prodor anglizacije. (Jesenšek 2018, 105-106)

Kot je že Slomška skrbelo znanje slovenščine med slovenskimi izobraženci, smo lahko ob globalizacijski angleščini na akademskem področju zelo zaskrbljeni tudi danes, saj to vodi v osiromašenje slovenskega znanstvenega jezika. Slovenščina sicer ostaja učni jezik univerzitetnega izobraževanja, ${ }^{8}$ a skrb vzbuja dejstvo, da veliko izobražencev raje uporablja angleščino kot pa knjižno slovenščino, poleg tega je znanje materinščine šibko tako med visokošolskimi profesorji kot tudi med študenti, ${ }^{9}$ slabša pa je tudi kakovost vsebin, saj lahko domači predavatelj vsebino bolje predstavi v materinščini kot pa v tujem jeziku. Ne nazadnje pomanjkanje stalnih znanstvenih objav v materinščini ne slabi le slovenskega strokovnega jezika, temveč celoten razvoj slovenščine, saj s tem ni uresničena njena polnofunkcijska raba, brez česar pa slovenščina ne more biti enakovreden jezik evropske večjezičnosti. (Žele 2018, 96) Po zgledu Slomška, ki je poskrbel za pouk slovenščine tako za bodoče duhovnike kot tudi za druge izobražence, bi nas take razmere morale spodbujati k razmisleku o slovenščini kot obveznem visokošolskem predmetu, bolj usmerjenem na posamezno študijsko področje in k razvijanju slovenskega znanstvenega in strokovnega jezika, na vseh študijskih smereh. Bodoče znanstvenike in strokovnjake naj bi "pripravljal na kompetentno in jezikovno kultivirano strokovno-znanstveno sporočanje « (Žele 2018, 95). ${ }^{10}$ Slomškova ustanovitev »celovške stolice za slovenski jezik« in njegova velika skrb za razvoj materinščine tudi na najvišji izobrazbeni stopnji poleg tega opozarja na pomembno vlogo učitelja oziroma predavatelja, ki je prvi odgovoren za razvoj najvišje

\footnotetext{
8 Več v Slavia Centralis 9/2 (2016): 51-98, Jesenšek 2016.

9 To nedvomno potrjuje šibka slovenščina npr. v diplomskih in drugih zaključnih delih.

10 Gre sicer za že pol stoletja staro pobudo, ki pa je uresničena le v redkih primerih.
} 
stopnje strokovnega jezika in za njegovo razširjanje od visokošolskega do srednjega in osnovnega šolanja. Ob tem ne gre samo za vprašanje slovenske jezikovne identitete, temveč tudi za moralno in kulturno vprašanje (Jesenšek 2018, 107), na kar je jasno opozarjal že Slomšek sredi 19. stoletja. S povečanjem veljave slovenskega jezika na vseh izobraževalnih stopnjah se oblikuje tudi učinkovit temelj za tako sobivanje $z$ drugimi jeziki, ki ne bo na njegovo škodo.

\section{Sklep}

Slomšek je prodorno razmišljal o jeziku in materni jezik postavil v temelj vsake izobrazbe, še zlasti bogoslovne, saj je v bodočih duhovnikih videl pomembne posredovalce maternega jezika med slovensko ljudstvo in utrjevalce njegove rabe v vseh funkcijskih zvrsteh. Njegovi temelji, ki jih je postavil z jezikovno vzgojo v celovškem bogoslovju, so najprej vplivali na slovensko šolstvo nasploh, nato pa tudi usmerjali nadaljnje dogodke, zlasti ko je leta 1859 prenesel sedež lavantinske škofije iz Šent Andraža v Maribor in še istega leta ustanovil bogoslovno učilišče v Mariboru, s čimer je postavil zgodovinski mejnik v razvoju slovenskega šolstva. Vsa ta Slomškova prizadevanja so zagotovo postavljala tudi temelje, na katerih je bila pred enainpetdesetimi leti ustanovljena enota Teološke fakultete UL v Mariboru.

Slomškova jezikovna prizadevanja $\mathrm{v}$ takratnem bogoslovnem izobraževanju so lahko izhodišče tudi v sodobnem teološkem študiju, zlasti za jezikovno načrtovanje znotraj njega v soočanju z vse bolj prodirajočimi globalizacijskimi jeziki. Slomšek je namreč zelo dobro vedel, da s slovensko jezikovno vzgojo v bogoslovnem izobraževanju med bodočimi duhovniki ohranja slovensko miselnost in slovensko kulturo, ki ju tudi v sodobnem slovenskem visokošolskem izobraževalnem sistemu ogrožajo težnje prevlade tujega, danes zlasti angleškega učnega jezika pred slovenskim. V svojem jezikovnem ozaveščanju je videl tudi možnost ustvarjanja večje jezikovne prepoznavnosti, kar tudi v sodobnosti vodi v učinkovitejše možnosti uresničevanja enakopravnega razvoja slovenščine znotraj evropske skupnosti. Slomšek je to še posebej dokazal v pridižni vzgoji, ki ji je med bogoslovci namenjal posebno pozornost, in oblikovanju 
umetniškega pridižnega jezika, ${ }^{11} \mathrm{~s}$ katerim je slovenski knjižni jezik iz povprečnosti in manjvrednosti povzdignil med druge evropske jezike. Pridiga mu je bila učinkovito sredstvo kultiviranja slovenskega naroda in jezika. Z njo je vzgajal svoje poslušalce $v$ najširšem pomenu in jim kazal, kako slovenska beseda lepo zveni in kako je lahko slovenski jezik sposoben vseh funkcijskih zvrsti. Slomšek je bil na tem področju edinstven, po njem namreč pridiga preide v svoje osnovne, oznanjevalne okvire. Vsak govorni položaj je izkoristil za kultiviranje slovenskega jezika, s čimer ostaja zgled in spodbuda sodobnemu učitelju/predavatelju glede uresničevanja zelo pomembne vloge pri ohranjanju in razvijanju slovenskega jezika ne glede na to, kateri predmet poučuje in na kateri stopnji izobraževanja.

11 Več o jezikovni in slogovni dovršenosti njegovih pridig piše Rezar (2015, 2019). 


\section{Reference}

Dermol Hvala, Hedvika. 2004. Analiza retoričnih prvin slovenskega narodnopolitičnega govorništva 19. stoletja. Magistrsko delo. Ljubljana: Fakulteta za družbene vede.

Grafenauer, Ivan. 1958-1959. Stolica za slovenski jezik na ljubljanskem liceju in Slomškovi tečaji v celovškem semenišču. Zgodovinski časopis 12-13: 272-282.

Jesenšek, Marko. 2003. Slomškov jezikovni nazor in slog. Slovenski knjižni jezik - aktualna vprašanja in zgodovinske izkušnje, Obdobja 20, 669-682. Ljubljana: Center za slovenščino kot drugi/tuji jezik pri Oddelku za slovenistiko Filozofske fakultete.

- - -. 2010. Slomškova rokopisna slovnica Inbegriff der slowenischen Sprache fur Ingeborne. Studia Historica Slovenica: časopis za humanistične in družboslovne študije 10: 667-682.

- - -. 2016. Slovenski jezik v visokem šolstvu, literaturi in kulturi (Zora 117). Maribor: Mednarodna založba Oddelka za slovanske jezike in književnosti, Filozofska fakulteta. https://doi. org/10.17161/1808.25032

- - -. 2018. Slovenščina kot učni jezik in jezik sporazumevanja v slovenskem šolstvu. Slavia Centralis 11: 105-118.

Kovačič, Franc. 1934. Služabnik božji Anton Martin Slomšek knezoškof lavantinski. Celje: Družba sv. Mohorja.

Melik, Vasilij. 1998. Slovenske dežele v Avstro-Ogrski. V: Marko Jesenšek, ur. Dajnkov zbornik (Zora 4), 27-34. Maribor: Slavistično društvo Maribor.
Orožen, Martina. 1991. Teoretični in praktični jezikovni nazori Slomška. V: Avguštin Lah, ur. 130 let visokega šolstva v Mariboru: zbornik simpozija, 366-382. Maribor, Celje: Škofijski ordinariat, Mohorjeva družba.

- - -. 1996. Oblikovanje enotnega slovenskega knjižnega jezika v 19. stolet$j u$. Ljubljana: Filozofska fakulteta, Znanstveni inštitut Filozofske fakultete.

- - -. 2010. Kulturološki pogled na razvoj slovenskega knjižnega jezika. (Zora 74). Maribor: Mednarodna založba Oddelka za slovanske jezike in književnosti, Filozofska fakulteta.

Rezar, Cvetka. 2014. Zametki jezikovne politike pri Antonu Martinu Slomšku. V: Marko Jesenšek, ur. Slovenski jezik na stičǐ̌ču več kultur. (Zora 102), 45-69. Maribor: Mednarodna založba Oddelka za slovanske jezike in književnosti.

- - -. 2015. Jezikovno-stilne značilnosti Slomškove pridige Od keršanske zloge ino edinosti u veri. Edinost in dialog 70: 123-134

- - -. 2019. Normativne in slogovne značilnosti Slomškovih pridig. Doktorska disertacija. Maribor: Filozofska fakulteta.

Slomšek, Anton Martin. 1821. Napelvavni govor k Slovenskimu zboru 1821. UKM, signatura Ms 11.

- - -. 1862: Vaje cerkvene zgovornosti. Drobtinice XVI: 3-46.

Žele, Andreja. 2018. Slovenščina v visokem šolstvu: sploh sme biti vprašanje ubesediti in opredeliti po slovensko?. Slavia Centralis 11: 93-104. 